Szükség van-e roma e-inclusion programokra?

Így hivatkozzon erre a cikkre:

Kurucz Erika. „Szükség van-e roma e-inclusion programokra?”.

A folyóiratban közölt müvek

a Creative Commons Nevezd meg! - Ne add el! - Így add tovább! 4.0

Nemzetközi Licenc feltételeinek megfelelően használhatók. 
Kurucz Erika

\section{Szükség van-e roma e-inclusion programokra?}

\section{8: az e-befogadás éve}

2008 az e-inclusion (e-befogadás) éve. Az EU hivatalosan is célul túzte ki, hogy elốsegíti az IKT-használat szempontjából hátrányos helyzetú, jelenleg a digitális szakadék „túlsó szélén” marginalizálódott társadalmi csoportok e-integrációját. Ez Magyarországon összesen közel hatmillió embert érint, ezt a számot kellene egy év alatt három millióra csökkenteni. Magyarországon ma leginkább az idôseket, a valamilyen fogyatékkal élók ${ }^{1}{ }^{1}$ és a roma népességet tekintjük hátrányos helyzetú csoportnak. Az utolsó népszámlálás adatai szerint a 60 év feletti időskorúak száma 2081559 fő, 577 ezer fő él fogyatékkal, ${ }^{2}$ és nagyságrendileg ezt a számot közelíti meg a roma népesség szociológusok (Kemény-Janky-Lengyel 2004) által 520-650 ezer före becsült csoportja is (ezek a halmazok nem diszjunktak, jelentôs átfedés van közöttük). A három csoport problémái és az alacsony IKT-használat mögött meghúzódó feltételezett okok azonban jelentôsen eltérnek egymástól. Az idôskorúak esetében életkorukból következik, hogy kevésbé fogékonyak az új dolgokra, és sokszor csökkenő szellemi képességeik (pl. fokozatos memóriacsökkenés, orientációcsökkenés, a kognitív folyamatok zavarai) is megnehezítik a tanulást. A fogyatékkal élók esetében a fogyaték maga az, ami korlátozhatja az egyén részvételét és lehetôségeit, hogy teljes mértékben aktív e-citizen lehessen. A roma népesség alacsony részvétele az információs társadalomban azonban nem „romakérdés” (sic!). Nem kötốdik a roma kultúrához, szokásokhoz, hanem sokkal inkább szegénygazdasági kérdés: a marginalizált, információhiányos, szociálisan és társadalmilag is hátrányos helyzet komplex következménye.

\section{Kellenek-e célzott roma e-inclusion programok?}

Az információs társadalomhoz tartozást gyakran dichotóm kategóriaként használjuk: vagy beletartozik valaki, vagy kiszorul (in or out). Valójában azonban ez nem dichotóm kategória: az emberek IKT-használat képességei meglehetôsen széles skálán mozognak. A használat módja, eszköze, idôtartalma, gyakorisága, célja, minősége, a lehívott tartalmak, a digitális írástudás foka stb. mind együtt határozzák meg, hogy az egyén hol helyezkedik el ezen a skálán, és mennyire integrálódik az információs társadalomba.

Az e-befogadás legelsố feltétele a számítógéphez és az internethez való hozzáférés biztosítása. A számítógép és az internet elérését azoknak a körében kell elôsegíteni,

\footnotetext{
${ }^{1}$ „Fogyatékkal élókön” a testi, értelmi vagy érzékszervi hátránnyal élő állampolgárokat értjük.

${ }^{2}$ Mindkét adat a www.nepszamlalas.hu oldalon található.
} 
akiknek nincs hozzáférésük, de szükségük van rá, illetve szeretnék, ha lenne. Hasonlóképpen, az IKT-használattal kapcsolatos készségeket, a digitális írástudást is azok esetében kell fejleszteni képzési és oktatási programok révén, akik ezekkel a készségekkel nem vagy csak alacsony szinten rendelkeznek. A korábbi IKT-eszközök, a telefon, a rádió, a televízió kezelése mára már nagyon leegyszerúsödött, felhasználóbaráttá vált, kezelésük alapkészségnek tekinthetô. Más a helyzet a számítógép és az internet világában, ahol a tanulást nem igénylố, egyszerúen használható funkciók mellett magasabb szintú tudást és technikai feltételeket megköveteló tevékenységekre is szükség van. A World Internet Project keretében végzett vizsgálatok ${ }^{3}$ eredményei szerint a roma társadalom esetében egyelốre az IKT-hozzáférés és a használat is alacsonyabb szintư, mint a többségi társadalomban.

A helyzet javítására „roma $e$-inclusion programként” indított projektek esetében azonban fennáll a veszély, hogy összemosódnak az etnikai hovatartozás és a szociális helyzet következményei, amelyek tovább erôsíthetik a társadalom tagjaiban a roma népességról élő negatív, elốitéletekkel terhelt képet. További következményként a romák virtuális világunkban is elkülönülő, felzárkóztatásra szoruló csoporttá degradálódnak. Ebból következik, hogy mind a roma népesség, mind az egész társadalom szempontjából az a jobb, ha ezek a programok nem „roma” címkével, hanem a szükségleti tényezóket hangsúlyozva jelennek meg, hiszen itt nem az egyébként is rendkívül rétegezett roma népesség jellemzóihez, kultúrájához kapcsolódó hátrányt kell kiegyenlíteni.

A hozzáférés biztosításán túl az e-inclusion programok alapvetô célja, hogy szervezett keretek között biztosítsák a hátrányos helyzetű egyének és közösségek számára a számítógéphez, internethez való hozzáférést és a használathoz szükséges készségek kialakulását. Fontos, hogy ezek az esélykiegyenlítő programok igazán hatékonyak legyenek, és az egyén személyes élményen keresztül, tapasztalati tanulás útján megismerje az IKT-eszközökben rejlố lehetôségeket, a számára releváns tartalmak elérésének módját, és elsajátítsa az autonóm használatot. Ez várhatóan megfelelốen motiválja majd arra, hogy használja ezeket az eszközöket, és ezáltal csökkenjen esetleges izoláltsága, és javuljon az életminősége. Ehhez azonban tudnunk kell, mely programok érik el a kívánt hatást, és melyek nem.

\section{A monitoring szerepe}

Magyarországon jelenleg még kevés olyan e-inclusion programot találunk, amely jelentős társadalmi hatást kiváltva a hátrányos helyzetú csoportok egy széles rétegét célozza meg és képes elérni. A meglevố programok leginkább az informatikához, telekommunikációhoz valami módon kapcsolódó cégek, civil szervezetek vagy lelkes, elkötelezett aktivisták által megvalósított egyedi kezdeményezések többnyire átfogó koncepció és kidolgozott indikátorrendszer nélkül. Általában nem kapcsolódik hozzájuk monitoringrendszer, nem készül róluk hatásvizsgálat, és ered-

\footnotetext{
${ }^{3}$ Lásd www.worldinternetproject.net
} 
ményeikról sincs objektív, elốre meghatározott indikátorok alapján készült elemzés. Ebból következốen tényleges hatásukról, eredményeikról nem sokat tudunk, és a hiányos információk miatt költséghatékonyságuk sem ítélhetố meg. Így az sem dönthetố el, hogy melyiket lehetne vagy kellene modellprogramként terjeszteni és fenntarthatóvá tenni, illetve melyiknek a múködését érdemes befejezni, esetleg átalakítani. A fenti hiányoknak leginkább a megcélzott csoportok látják közvetlen kárát, de közvetetten, hosszabb távon az ország versenyképességét is kedvezôtlenül befolyásolják. Egyes korábbi társadalmi integrációs programoknál az adatvédelmi törvény korlátai miatt már a célcsoport megtalálásánál, kiválasztásánál is voltak problémák. Míg az idôskorúak születési dátumuk, a fogyatékkal élốk pedig hátrányos tulajdonságuk alapján jól azonosíthatók, addig a roma célcsoport esetében - az önazonosítás, illetve a külső szakértő által végzett meghatározás eltérései miatt mindig komoly módszertani problémaként vetődik fel a „Ki a roma?” kérdés Ez további érv amellett, hogy az e-inclusion programok célcsoportjának kiválasztásánál a szükségletnek kell a döntő szempontnak lennie.

A jól megtervezett, célindikátorokat és eredményindikátorokat is tartalmazó e-inclusion programok lehetôséget teremtenének arra, hogy a hátrányos helyzetú, kevésbé integrált csoportok valódi lehetốséget kapjanak az e-befogadásra. Azt, hogy valamely programnak van-e tényleges hatása, és az megegyezik-e a szándékolt hatással, csak akkor tudhatjuk meg, ha már a projekt megkezdése előtt, a tervezési szakaszban rögzítjük azokat a mutatókat, amelyekkel a hatást és az eredményeket majd mérni tudjuk. Csak a kiinduló értékekhez viszonyítva tudjuk mérni a változásokat. Ebból következik, hogy nélkülük a programok utólagos hatásvizsgálata nem lehetséges. A legfontosabb rögzítendố mutatók a forrás- vagy input-indikátorok, melyek segítségével a projekt költségei mellett számszerúsíthetók a technikai, humán és szervezeti erốforrások. A célindikátorok vagy output-indikátorok a tevékenységek nyomán létrejövố közvetlen eredményeket számszerúsítik, általában fizikai tulajdonságokat mérve. Az eredmény vagy teljesítmény-indikátorokat is meg kell határozni, ezek a projekt azonnali és közvetlen eredményeiról nyújtanak majd információt. Végül definiálni kell a hatás-indikátorokat is, melyek a projekt következtében rendszerint hosszabb távon jelentkezó közvetlen hatásokat mutatják meg. Ezek segítségével a program az egész megvalósítás alatt jól követhetố, mérhetố és szükség esetén fejleszthetố.

Az e-inclusion programoknál különösen fontos, hogy elốzetesen történjen szü̈ségletfelmérés, amelyból pontosítani lehet, hogy milyen igényei vannak a célcsoportnak. A motiváció kialakítása, a megfelelő információk átadása a célcsoportnak a programról és a lehetőségekról, a kérdéseik folyamatos megválaszolása és az esetlegesen felmerüló problémák idóbeni kezelése döntő fontosságú a program sikere szempontjából. Elengedhetetlen továbbá a folyamatos monitoring a projekt során, amelyhez bizonyos minóségbiztositásnak, minóségfejlesztésnek is társulnia kell - ezt a célt szolgálhatja például a célcsoport elégedettségi vizsgálata, a belsố folyamat-ellenốrzés, az úgynevezett mérföldkövek meghatározása stb. -, és a projekt folyamán így lehetôség nyílik a módosításra, javításra, fejlesztésre. A jól kialakított monitoringrendszer objektíven mérhetố eredményư és hatású, eredményes e-inclusion programokat biztosít, amelyek hosszú távon nemcsak a célcsoport integrálódását segítik elő, hanem hatékonyan hozzájárulnak az ország gazdasági versenyképességének javulásához is. 


\section{Irodalom}

Kemény István - Janky Béla - Lengyel Gabriella 2004. A magyarországi cigányság, 1971-2003. Budapest, Gondolat Kiadó-MTA Etnikai-Nemzeti Kisebbségkutató Intézet.

Magyar Információs Társadalom Éves Jelentés, 2006.

http://www.ittk.hu/web/docs/ITTK_MITJ_2006.pdf

World Internet Project, 2001-2006. http://www.worldinternetproject.net/

2001. évi népszámlálás. http://www.nepszamlalas.hu 